\title{
Review \\ The Pharmacology of Xenobiotics after Intracerebro Spinal Fluid Administration: Implications for the Treatment of Brain Tumors
}

\author{
Justine Paris ${ }^{1,+}$, Eurydice Angeli ${ }^{1,2,3,+}$ and Guilhem Bousquet 1,2,3,*(D) \\ 1 Institut National de la Santé Et de la Recherche Médicale (INSERM), U942, 9 Rue de Chablis, \\ 93000 Bobigny, France; justinesv.paris@gmail.com (J.P.); eurydice.angeli@gmail.com (E.A.) \\ 2 Assistance Publique Hôpitaux de Paris, Avicenne Hospital, Department of Medical Oncology, \\ 93000 Bobigny, France \\ 3 Sorbonne Paris Nord University, 99 Avenue Jean Baptiste Clément, 93430 Villetaneuse, France \\ * Correspondence: guilhem.bousquet@aphp.fr \\ + These authors are co-first authors.
}

Citation: Paris, J.; Angeli, E.;

Bousquet, G. The Pharmacology of Xenobiotics after Intracerebro Spinal Fluid Administration: Implications for the Treatment of Brain Tumors. Int. J. Mol. Sci. 2021, 22, 1281. https://doi.org/10.3390/ ijms22031281

Academic Editor: Alessandro Frati Received: 31 December 2020

Accepted: 26 January 2021

Published: 28 January 2021

Publisher's Note: MDPI stays neutral with regard to jurisdictional claims in published maps and institutional affiliations.

Copyright: (c) 2021 by the authors. Licensee MDPI, Basel, Switzerland. This article is an open access article distributed under the terms and conditions of the Creative Commons Attribution (CC BY) license (https:// creativecommons.org/licenses/by/ $4.0 /)$.

\begin{abstract}
The incidence of brain metastasis has been increasing for 10 years, with poor prognosis, unlike the improvement in survival for extracranial tumor localizations. Since recent advances in molecular biology and the development of specific molecular targets, knowledge of the brain distribution of drugs has become a pharmaceutical challenge. Most anticancer drugs fail to cross the blood-brain barrier. In order to get around this problem and penetrate the brain parenchyma, the use of intrathecal administration has been developed, but the mechanisms governing drug distribution from the cerebrospinal fluid to the brain parenchyma are poorly understood. Thus, in this review we discuss the pharmacokinetics of drugs after intrathecal administration, their penetration of the brain parenchyma and the different systems causing their efflux from the brain to the blood.
\end{abstract}

Keywords: brain metastases; blood-brain barrier; intrathecal injection; glymphatic system; efflux receptor; neonatal Fc receptor

\section{Introduction}

Since 1914 and the development of salvarsan to treat syphilis and its neurological damage, penetration of drugs into the brain has continued to be a pharmaceutical challenge [1] The central nervous system is a sanctuary site, highly protected from the outside environment by the low permeability of the blood-brain barrier (BBB) and by efflux systems preventing brain penetration and diffusion of most xenobiotics [2]. Since recent advances in molecular biology and the development of specific molecular targets, knowledge of the brain distribution of drugs has become a pharmaceutical challenge.

Among the different cancer types, the incidence of brain metastases ranges from $9 \%$ to $30 \%$ across studies [3-7]. Melanoma, breast and lung cancers are the main providers of brain metastases which occur in 6 to $56 \%$ of patients [3], and lead to short survival of under a year [8]. To date, standard treatments are more or less limited to surgery and radiotherapy $[9,10]$.

Systemic anticancer treatments, including the classic chemotherapies and targeted treatments, have a limited benefit on cancer brain metastases because they do not readily cross the $\mathrm{BBB}$, thus obtaining only insufficient pharmacological concentrations in the brain [2].

To overcome this problem, direct intrathecal injections of drugs have been proposed for the treatment of carcinomatosis meningitidis and parenchymal brain metastases [11,12]. However, little is known about drug pharmacokinetics in the brain parenchyma after intracerebrospinal fluid administration.

In this review, we provide a summary of knowledge on drug penetration into the brain parenchyma after intracerebrospinal fluid injection and the different systems causing their efflux. 


\section{Turnover in the Glymphatic System}

Brain extracellular spaces occupy $20 \%$ of the total brain volume [13], including fluid compartments with blood vessels, cerebrospinal fluid (CSF) and intracellular fluid.

On the cortical surface of the brain, the cerebral arteries extend into the pial arteries running through the subarachnoid and subpial spaces. When they penetrate the brain parenchyma, the pial arteries create a perivascular space filled with CSF and bordered by leptomeningeal cells, known as the Virchow-Robin space. As the pial arterioles penetrate the deeper brain parenchyma, the Virchow-Robin spaces become continuous with the basal lamina, which separate endothelial cells, pericytes and astrocytes. Unlike peripheral tissues, the central nervous system completely lacks lymphatic vessels [14].

Since 1981, various experiments have been carried out by H. F. Cserr's team to assess the clearance of physiological molecules and xenobiotics after their intracerebral administration. Despite major differences in molecular sizes and diffusion coefficients, efflux rates are roughly similar, whatever the molecule considered, suggesting a convective system of brain circulation and efflux, independent from the blood-brain barrier [15].

This system, called the glymphatic system, is driven by pressure gradients along arterial and venous perivascular spaces [16] (Figure 1a,b), and has an important role in the distribution and clearance of molecules and toxins. Radio-labelled tracer studies indicate that 40 to $80 \%$ of large proteins and solutes are removed from the brain by the glymphatic clearance system [13].

(a)

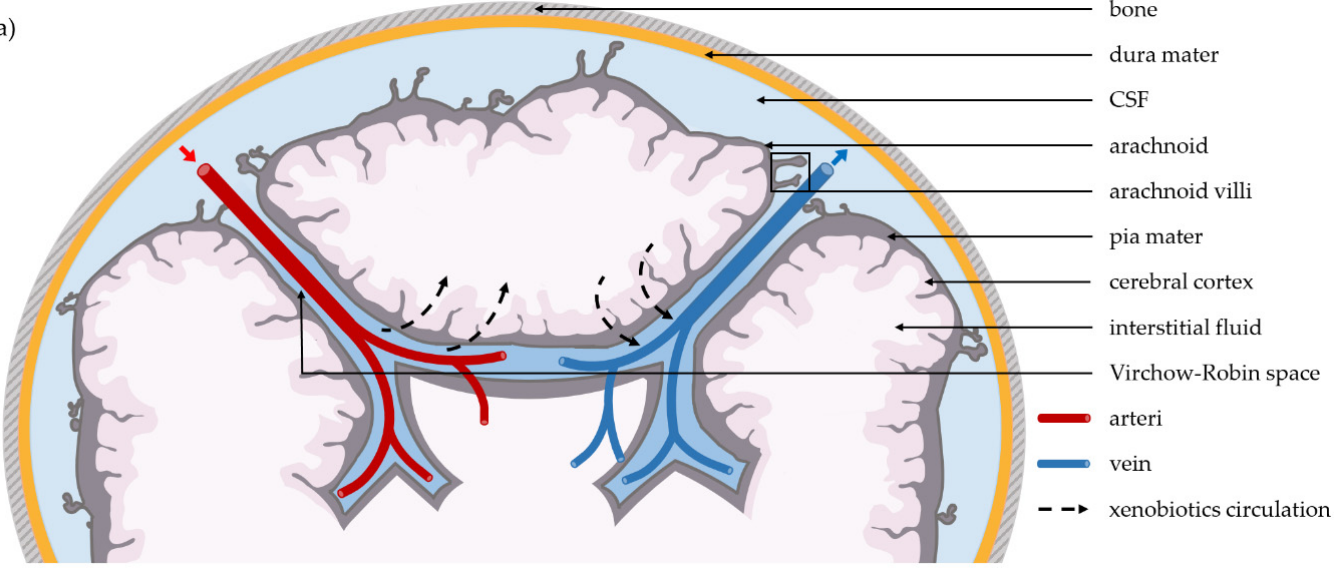

(b)

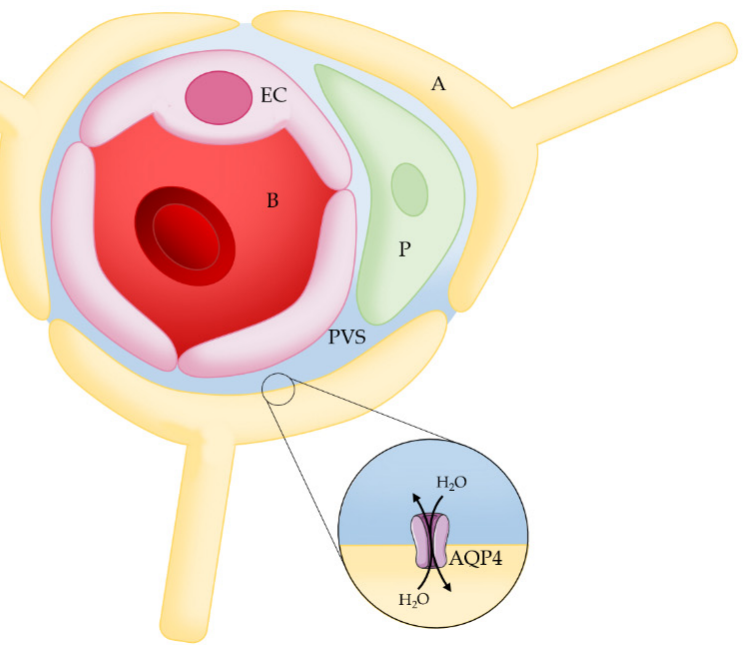

Figure 1. Anatomical structures of brain vasculature. (a) The glymphatic system: xenobiotics circulation, diffusion and efflux along perivascular spaces after intrathecal administration. (b) Cross section of a brain vessel: xenobiotics circulate along perivascular spaces of blood vessels. A: astrocyte, regulator of the hydrostatic pressure by water exchanges; AQP4: aquaporin 4; P: pericyte; EC: endothelial cell; PVS: perivascular space; B: blood. (Images modified from (C) SMART/CC-BY-3.0). 


\subsection{Transport through the Glymphatic System, Astrocyte Regulation Function}

Illif et al. [17] studied the mouse brain distribution of fluorescent and radio-labelled tracers after intrathecal administration. First, they evidenced an absence of brain penetration when drugs were injected into the ventricles, while global brain penetration varied from 20 to 95\% after injections into the cisterna magna. Low molecular weight molecules (TR-d $3,3 \mathrm{kD}$ ) penetrate the brain interstitial fluid from perivascular spaces and the pial surface, while larger molecular weight molecules (FITC-d2000, $2000 \mathrm{kD}$ ) remain in the perivascular spaces of penetrating arteries and do not reach the interstitial fluid. Using two photon laser scanning microscopy, fluorescent dextran was able to penetrate brain parenchyma after injection into the cisterna magna and confirmed the passage of small molecules (TR-d3) into the brain interstitium, while larger molecules (FITC-d2000) remained confined to the paravascular spaces of penetrating arteries. After injection, the smaller tracers rapidly entered the brain via surface cortical arteries, in the space surrounding the arterial smooth muscle cells. They then reached the penetrating arterioles and the terminal capillary bed, circulating in a space bounded by astrocytic endfeet. Finally, fluorescent tracers rapidly reached deeper brain structures like the basal ganglia and the thalamus.

Perivascular astrocytes, which almost entirely cover the brain microvasculature [18], play a major role in CSF and brain interstitial fluid distribution and bulk flow. First, astrocytic endfeet may have a sieving function, allowing the passage of molecules smaller than $20 \mathrm{~nm}$ into the brain interstitium, corresponding to the space between two overlapping endfeet [18]. Secondly, they regulate the flow of water by the expression of aquaporin 4 at their endfeet. A knockout mouse model for aquaporin 4 showed a cessation of tracer movements from the distal paravascular space to the interstitium, and of interstitial bulk clearance from the brain parenchyma $[17,19]$. By creating an arterio-venous hydrostatic pressure gradient, aquaporin 4 facilitates the influx of subarachnoid CSF from para-arterial spaces into the brain interstitium and the clearance of brain interstitial fluid to the extracerebral area.

Other factors are responsible for hydrostatic pressure modifications in the glymphatic system and the accumulation of toxins. One study demonstrated a reduction of $80-90 \%$ for glymphatic flux in elderly mice compared to young mice, leading to an accumulation of tau and amyloid $\beta$ peptide [20]. This can be due to a reduction of arterial pulsatility, because of the stiffening of the arterial wall in elderly people [21,22], or a reduction of CSF production $[21,23,24]$. In contrast, a sleeping state (anesthetized or naturally sleeping) significantly improves the performance of glymphatic activity, with a $90 \%$ higher CSF flow in the waking state as was demonstrated in rats [25].

\subsection{Drug Diffusion in the Extracellular Space of Brain}

Drug diffusion in the extracellular space responds to diffusion mechanisms, driven by the kinetic energy of molecules and their collision with water molecules. This is influenced by many biochemical and physical parameters [13]. Wolak et al. assessed drug diffusion ratios in the extracellular space of brain after intrathecal administration. They demonstrated that low molecular weight molecules, with a small hydrodynamic diameter and absence of fixation to negatively charged heparan sulfates, widely diffused in the extracellular space, reaching deep brain structures [13].

\subsection{Clearance of the Cerebral Interstitial Fluid}

Patlak et al. studied the efflux of radio-iodinated albumin after injection into the caudate nucleus, the internal capsule and the midbrain of rats [26]. After distribution in the interstitial fluid from the perivascular spaces, $62 \%$ of cerebral interstitial fluid drains into the CSF. Pharmacokinetic studies have demonstrated that tracers were cleared from the subarachnoid space: (i) to the blood through the arachnoid villi or fenestrated vessels of the choroid plexus $[15,26,27]$, (ii) to the retropharyngeal lymph nodes through the cribriform plate or the sheath of olfactory nerves [28].

Using Tie2-GFP:NG2-DsRed double reporter mice that enable arteries and veins to be distinguished on tissue sections, other authors have observed that tracers accumulate 
within the perivascular spaces of capillaries and parenchymal venules one hour after intracisternal injections [17]. The tracers then exited the brain via para-venous routes of the medial internal cerebral veins and the lateral-ventral caudal rhinal veins. These results demonstrate that interstitial cerebral fluid and CSF circulate and are cleared via the same para-arterial and para-venous spaces in the glymphatic system.

Finally, the glymphatic system plays a role in xenobiotic distribution in the brain after intracerebral or intrathecal administration. It also enables the elimination of molecules that are too large to cross the BBB or that lack specific receptors [29]. This convective system is closely regulated by the aquaporin 4 channels of astrocytic endfeet.

\section{Efflux Systems and Drug Clearance}

As the BBB restricts large hydrophilic molecules from entering the brain parenchyma, direct injection of xenobiotics into the cerebrospinal fluid is a promising method to bypass the lack of permeability of the blood-brain barrier [30,31]. However, this approach has limitations, since drug transporters are responsible for an active efflux of xenobiotics from brain to blood. These transporters, mainly ATP-binding cassette $(\mathrm{ABC})$ transporters and neonatal Fc receptor ( $F c R n)$, are expressed by endothelial cells in the BBB. This efflux, by preventing drugs from reaching relevant concentrations in the brain parenchyma, could explain their limited efficacy after intravenous administration and also after intracerebrospinal fluid administration [32-37].

\subsection{ABC Transporters}

The $A B C$ gene family codes for $48 \mathrm{ABC}$ transporters, which use energy from ATP hydrolysis to transport substrates across biological membranes, and six of them are implicated in drug transport [38]. For the BBB, the most widely studied $A B C$ efflux transporters are the P-glycoprotein (Pgp), the breast cancer resistance protein (BCRP) and the multidrug resistance protein (MRP) [39] (Figure 2).

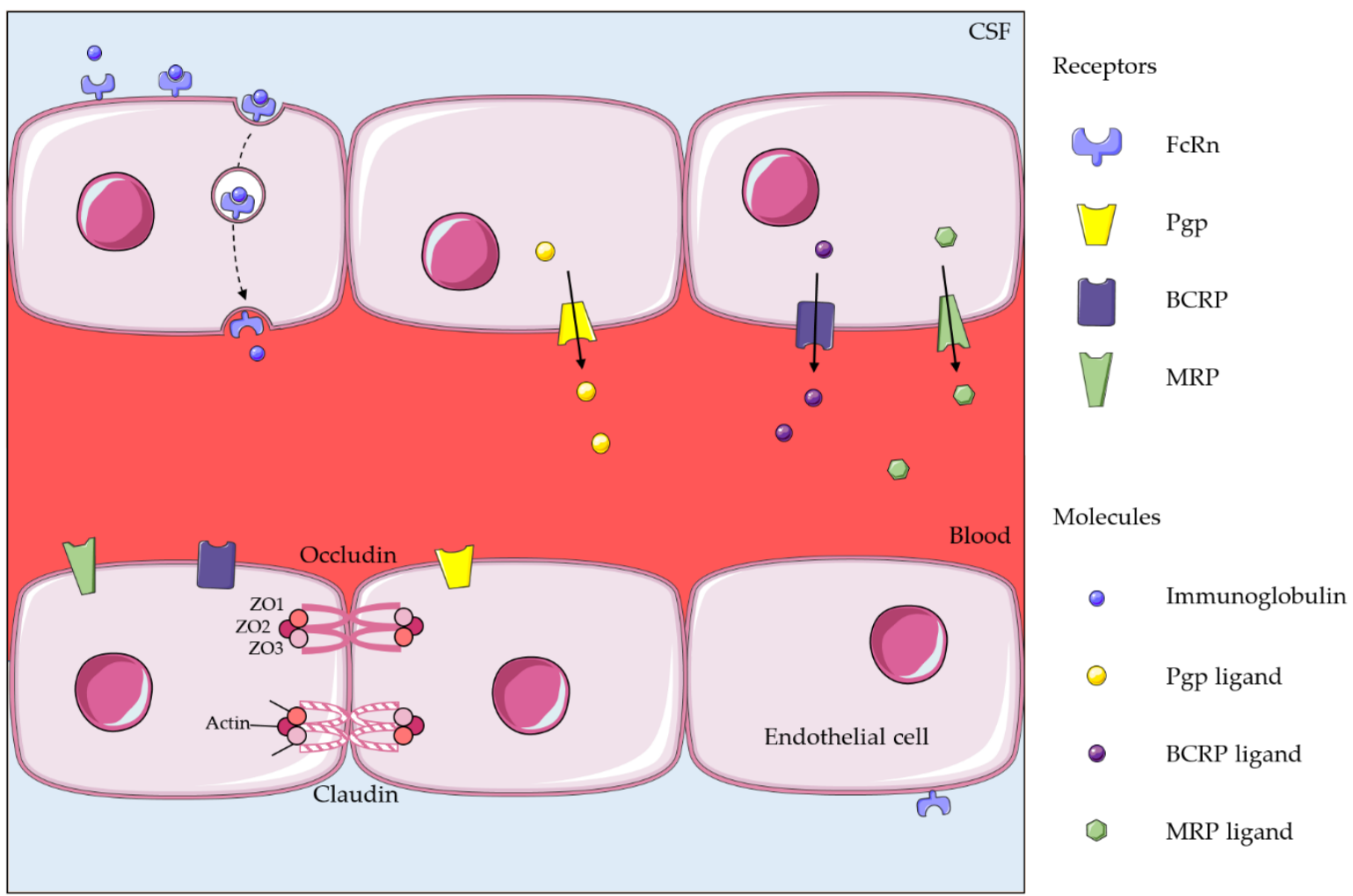

Figure 2. Efflux systems on the BBB (blood-brain barrier). Left side: transcytosis across endothelial cells of the BBB by FcRn. Middle and right side: $\mathrm{ABC}$ transporters at the luminal side of endothelial cells of the BBB. ZO: zonula occludens. (Images modified from (C) SMART/CC-BY-3.0). 
In humans, the Pgp is a $170 \mathrm{kDa}$ plasma membrane protein of the $\mathrm{ABC}$ subfamily B member 1. It is encoded by two members of the Pgp gene family, MRD1 and MRD3. In Mus musculus, Pgp is encoded by three genes, $m r d 1, m r d 2$ and $m r d 3$ [40]. Only MRD1 proteins in humans, and mrd1 and mrd3 proteins in Mus musculus, enable multidrug transport through the BBB [41-44].

Pgp was identified in 1976 in Chinese hamster ovary cells [45]. In 1987, on a panel of eight mammalian cell lines, expression of the Pgp protein was associated with a multidrug resistance phenotype towards 15 anticancer drugs [46]. In human tissues obtained after surgery or autopsy procedures, following immunostaining, Pgp was mainly expressed by liver cells, renal tubule cells and gut endothelial cells, suggesting its role in the physiological elimination of xenobiotics $[47,48]$. In the human brain, Pgp was strongly expressed in the apical membrane of capillary endothelial cells [49-51], and also by astrocyte endfeet covering endothelial cells in the BBB [52]. This physiological expression at the BBB suggests a protective role of Pgp, promoting xenobiotic efflux from brain to blood. Even if Pgp shares the same function across species, its expression level at the BBB seems to be species dependent, and 3-times higher in human brain samples obtained from autopsy than in brain tissue obtained from Sprague Dawley laboratory rats [53]. Knockout mice lacking the functional homologue of human MDR1 protein have an abnormal accumulation of drugs in the brain parenchyma [54]. Surprisingly, when in vitro cell lines are exposed to increasing concentrations of a drug, the expression level of Pgp also increases [55,56]. This could be explained by the fact that Pgp expression, in addition to its physiological expression, is also inducible. More recently, in vitro and in vivo preclinical studies have evidenced drug-inducible expression of Pgp in response to exposure to certain xenobiotics $[57,58]$.

In cancer patients with brain metastases or primary brain tumours, Pgp expression at the BBB is challenging clinical practice, since Pgp recognizes various cancer drugs (Table 1). To favour BBB passage and prevent drug efflux linked to Pgp expression, Pgp inhibitors have been tested in preclinical models, with promising results $[59,60]$. The aim was to increase drug accumulation in the brain parenchyma, including anticancer drugs (Table 2). Typically for taxanes (paclitaxel or docetaxel), combining their administration with Pgp inhibitor increases their brain parenchyma penetration 2- to 6-fold. However, it appears that Pgp inhibitors are less effective in inhibiting Pgp at the BBB than in other localizations [61], so that the use of higher doses is required, thus possibly entailing greater toxicity. In humans, the data are still limited. In healthy volunteers, a pilot study has shown that oral administration of tariquidar, a third generation Pgp inhibitor, increases the brain distribution volume of (R)- ${ }^{11} \mathrm{C}$-verapamil by $24 \%$ compared to (R)- ${ }^{11} \mathrm{C}$-verapamil only [62].

Finally, an additional complexity is linked to the possible activation of Pgp activity through conformational change induction, as shown with oxygenated xanthones $[63,64]$.

$\mathrm{BCRP}$ is predominantly expressed in the luminal membrane of BBB endothelial cells $[65,66]$. It is implicated in drug resistance to several tyrosine kinase inhibitors, such as imatinib and gefitinib [67-69]. BRCP knockout mice showed an increased brain penetration of xenobiotics [70-74]. Even if Pgp is the main efflux transporter [75], BCRP and Pgp concomitantly act as efflux transporters, BCRP being more rapidly saturated than Pgp [76]. BCRP and Pgp have compensatory systems and probably need to be inhibited simultaneously to increase the brain distribution of drugs.

MRP is ubiquitously expressed in several tissues including the luminal membrane of BBB endothelial cells [77-79] and it acts as an anion transporter and also as a drug transporter [80]. Indeed, several drugs are both substrates for Pgp and MRP transporters (Table 1) as they have a synergistic and overlapping role in reducing the entrance of xenobiotics into the brain [81]. 
Table 1. ABC transporter substrates.

\begin{tabular}{|c|c|c|c|}
\hline $\begin{array}{c}\text { ABC Transporters } \\
\text { (Corresponding Gene) }\end{array}$ & Substrates & Biological Effect & Reference \\
\hline \multicolumn{4}{|c|}{ Anticancer drug } \\
\hline \multirow{20}{*}{$\begin{array}{c}\text { Pgp } \\
(A B C B 1)\end{array}$} & Paclitaxel & Microtubule polymer stabilizer & {$[82,83]$} \\
\hline & Docetaxel & Microtubule-disruptive drug & {$[83,84]$} \\
\hline & Vinblastine & Microtubule-disruptive drug & [83] \\
\hline & Vincristine & Topoisomerase II inhibitor & [83] \\
\hline & Mitoxantrone & Topoisomerase II inhibitor & [83] \\
\hline & Etoposide (VP16) & Topoisomerase II inhibitor & [83] \\
\hline & Doxorubicin & DNA intercalating agent & {$[83]$} \\
\hline & Daunorubicin & DNA intercalating agent & [83] \\
\hline & Afatinib & EGFR-TKI & [85] \\
\hline & Erlotinib & EGFR-TKI & {$[85,86]$} \\
\hline & Gefitinib & EGFR-TKI & {$[85,86]$} \\
\hline & Osimertinib & EGFR-TKI & {$[85,86]$} \\
\hline & Rociletinib & EGFR-TKI & [85] \\
\hline & \multicolumn{2}{|c|}{ Anti-arrhythmic agent } & \\
\hline & Digoxin & Sodium pump inhibitor & [87] \\
\hline & \multicolumn{2}{|c|}{ Anti-retroviral drug } & \\
\hline & Ritonavir & Protease inhibitor & [88] \\
\hline & Saquinavir & Protease inhibitor & [88] \\
\hline & & lammatory & \\
\hline & Colchicine & Microtubule assembly inhibitor & [89] \\
\hline \multirow{4}{*}{$\begin{array}{c}\text { MRP } \\
(A B C C 1)\end{array}$} & \multicolumn{2}{|c|}{ Anticancer drug } & \\
\hline & Etoposide (VP16) & Topoisomerase II inhibitor & [83] \\
\hline & \multicolumn{2}{|c|}{ Anti-inflammatory } & \\
\hline & Colchicine & Microtubule assembly inhibitor & [89] \\
\hline \multirow{4}{*}{$\begin{array}{c}\text { MRP } \\
(A B C C 2)\end{array}$} & \multicolumn{2}{|c|}{ Anticancer drug } & \\
\hline & Vinblastine & Microtubule-disruptive drug & {$[83,90]$} \\
\hline & \multicolumn{2}{|c|}{ Uricosuric drug } & \\
\hline & Sulfinpyrazone & Degranulation of platelets inhibitor & [90] \\
\hline \multirow{8}{*}{$\begin{array}{c}\text { MRP } \\
(A B C C 3)\end{array}$} & \multicolumn{2}{|c|}{ Anticancer drug } & \\
\hline & Topotecan & Topoisomerase I inhibitor & [83] \\
\hline & Camptotecin (CPT-11) & Topoisomerase I inhibitor & [91] \\
\hline & Etoposide (VP16) & Topoisomerase II inhibitor & [83] \\
\hline & Mitoxantrone & Topoisomerase II inhibitor & [83] \\
\hline & Doxorubicin & DNA intercalating agent & [83] \\
\hline & Daunorubicin & DNA intercalating agent & [83] \\
\hline & Methotrexate & Dihydrofolate reductase inhibitor & [92] \\
\hline
\end{tabular}


Table 2. Brain exposure to xenobiotics combined with Pgp inhibitors in preclinical studies.

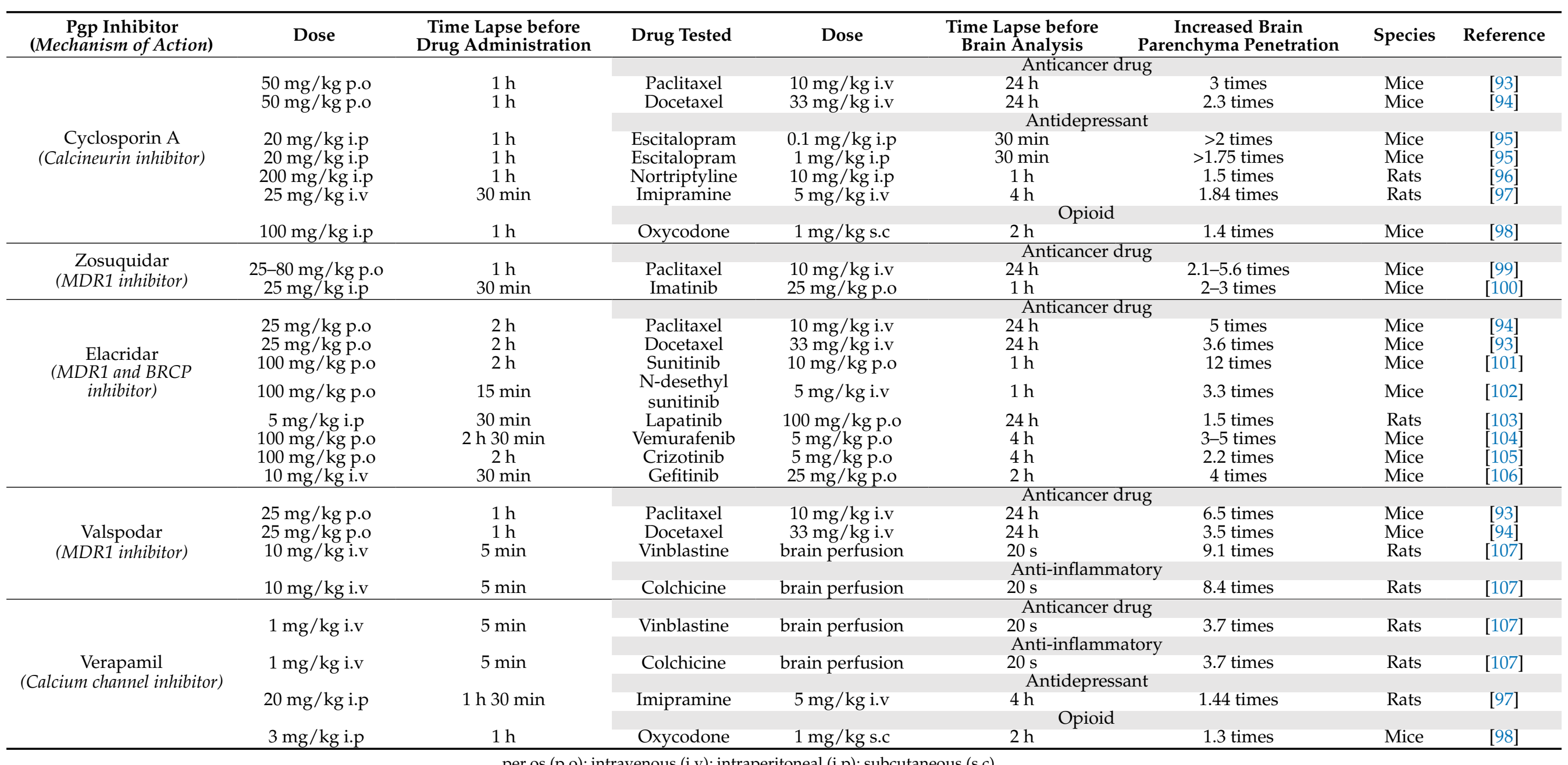




\subsection{FcRn}

FcRn, a heterodimer belonging to the major histocompatibility class I complex, is physiologically and ubiquitously expressed in humans, particularly in placental endothelial cells and in epithelial cells from the gut $[108,109]$. FcRn enables IgG and albumin to escape endothelial catabolism and transcytosis, thus promoting their biodistribution in the body. In particular, FcRn receptor enables fetal immunity through transfer of maternal immunoglobulins across the placenta [110,111].

In 2002, FcRn receptor expression was demonstrated for the first time in microvascular endothelial cells from rat brain using immunochemistry [112]. FcRn is expressed in the abluminal side of the endothelial cells of the BBB, and is involved in the transcytosis of immunoglobulins from brain to blood [113]. In a rat model, intracranial administration of two variants of a recombinant human immunoglobulin G1, one with high FcRn affinity and the other with low FcRn affinity, led to a high brain-to-blood efflux of the high FcRn affinity immunoglobulins [113]. Once the Fc fragment of the immunoglobulin binds to the FcRn receptor, an endocytosis process allows the immunoglobulin to enter the cytoplasm of the endothelial cell, and to be further expelled to the luminal side by an exocytosis process, as shown in vitro using fluorescent imaging [114,115] (Figure 2). Saturation can be reached after addition of the Fc fragment but not the Fab fragment of immunoglobulins [33].

In cancer patients, several approaches are being explored to improve brain penetration of drugs. Two methods are being developed to overcome the blood-brain barrier: (i) disruption of the blood-brain barrier, including intrathecal administration [11,12,116], intra-arterial administration [2,117-122], mechanical disruption of the BBB using osmotherapy [123], radiation [124,125] or ultrasounds [126]; (ii) methods without disruption of the BBB, for instance nano functionalization of drugs to cross the BBB or intranasal administration $[2,127]$. To date, most clinical approaches use the intrathecal route with a lumbar or an Ommaya reservoir, since direct intrathecal injections of drugs have led to some clinical benefit for the treatment of carcinomatosis meningitidis and parenchymal brain metastases $[11,12,128,129]$. This approach is simple and safe in daily practice but requires strict asepsis [130].

Even if these innovative approaches enable drugs to penetrate brain parenchyma, efflux transporters prevent relevant pharmacological concentrations from being reached. This is particularly true for therapeutic monoclonal antibodies, probably via FcRn receptors. In a pilot clinical study, our research team demonstrated considerable and rapid efflux of trastuzumab, an anti-HER2 IgG1, from CSF to blood after intrathecal administration [129]. Injections three times a week were required to reach relevant trastuzumab concentrations in the CSF, providing clinical efficacy in halting brain metastasis progression. Engineering therapeutic Fab fragments could be a way to overcome this limitation.

\section{Conclusions}

Brain metastases remain a major therapeutic challenge, since standard treatments have limited efficacy. Since primary tumors and metastases, including brain metastatic localizations, frequently share common genomic signatures [2], we assume a similar theoretical efficacy of targeted therapies on brain and extracentral nervous system metastases on the condition that there is sufficient pharmacological exposure. As a result, the same drug screening methods can be used, especially pre-clinical in vivo models of patient-derived xenografts, particularly relevant tools for the treatment of metastatic cancers [131]. It is however interesting to note that orthotopic patient-derived xenografts of brain metastases encounter the same problems of low permeability of the blood-brain barrier to drugs after intravenous injection, and that their use for the preclinical development of drugs should probably involve the intrathecal route of drug administration.

The intrathecal route has been proposed to facilitate drug access to the brain parenchyma via the glymphatic system. Diffusion into deeper brain areas depends on the molecular weight and the biochemical characteristics of drugs, and also on efflux systems from the 
BBB. Further studies are required to overcome these limitations and efficiently treat cancer brain metastases.

Author Contributions: Conceptualization, J.P., E.A. and G.B.; methodology, J.P., E.A. and G.B.; validation, G.B.; writing-original draft preparation, J.P. and E.A.; writing-review and editing, J.P. and E.A; supervision, G.B.; project administration, G.B. All authors have read and agreed to the published version of the manuscript.

Funding: This research received no external funding.

Informed Consent Statement: Not applicable.

Conflicts of Interest: The authors declare no conflict of interest.

\section{Abbreviations}

$\begin{array}{ll}\text { ABC } & \text { ATP-Binding Cassette } \\ \text { BBB } & \text { Blood-Brain Barrier } \\ \text { BCRP } & \text { Breast Cancer Resistance Protein } \\ \text { CSF } & \text { Cerebrospinal Fluid } \\ \text { FcRn } & \text { Neonatal Fc Receptor } \\ \text { MRD } & \text { Multidrug Resistance Protein } \\ \text { Pgp } & \text { P-Glycoprotein }\end{array}$

\section{References}

1. Pardridge, W.M. CNS drug design based on principles of blood-brain barrier transport. J. Neurochem. 1998, 70, 1781-1792. [CrossRef]

2. Angeli, E.; Nguyen, T.T.; Janin, A.; Bousquet, G. How to Make Anticancer Drugs Cross the Blood-Brain Barrier to Treat Brain Metastases. Int. J. Mol. Sci. 2019, 21, 22. [CrossRef]

3. Nayak, L.; Lee, E.Q.; Wen, P.Y. Epidemiology of brain metastases. Curr. Oncol. Rep. 2012, 14, 48-54. [CrossRef]

4. Suh, J.H.; Kotecha, R.; Chao, S.T.; Ahluwalia, M.S.; Sahgal, A.; Chang, E.L. Current approaches to the management of brain metastases. Nat. Rev. Clin. Oncol. 2020, 17, 279-299. [CrossRef]

5. Scoccianti, S.; Ricardi, U. Treatment of brain metastases: Review of phase III randomized controlled trials. Radiother. Oncol. 2012, 102, 168-179. [CrossRef]

6. Tsukada, Y.; Fouad, A.; Pickren, J.W.; Lane, W.W. Central nervous system metastasis from breast carcinoma. Autopsy study. Cancer 1983, 52, 2349-2354. [CrossRef]

7. Sampson, J.H.; Carter, J.H., Jr.; Friedman, A.H.; Seigler, H.F. Demographics, prognosis, and therapy in 702 patients with brain metastases from malignant melanoma. J. Neurosurg. 1998, 88, 11-20. [CrossRef]

8. Lowery, F.J.; Yu, D. Brain metastasis: Unique challenges and open opportunities. Biochim. Biophys. Acta Rev. Cancer 2017, 1867, 49-57. [CrossRef]

9. Caroli, M.; Di Cristofori, A.; Lucarella, F.; Raneri, F.A.; Portaluri, F.; Gaini, S.M. Surgical brain metastases: Management and outcome related to prognostic indexes: A critical review of a ten-year series. ISRN Surg. 2011, 2011, 207103. [CrossRef]

10. Ramakrishna, N.; Temin, S.; Chandarlapaty, S.; Crews, J.R.; Davidson, N.E.; Esteva, F.J.; Giordano, S.H.; Gonzalez-Angulo, A.M.; Kirshner, J.J.; Krop, I.; et al. Recommendations on disease management for patients with advanced human epidermal growth factor receptor 2-positive breast cancer and brain metastases: American Society of Clinical Oncology clinical practice guideline. J. Clin. Oncol. 2014, 32, 2100-2108. [CrossRef]

11. Bonneau, C.; Paintaud, G.; Tredan, O.; Dubot, C.; Desvignes, C.; Dieras, V.; Taillibert, S.; Tresca, P.; Turbiez, I.; Li, J.; et al. Phase I feasibility study for intrathecal administration of trastuzumab in patients with HER2 positive breast carcinomatous meningitis. Eur. J. Cancer 2018, 95, 75-84. [CrossRef] [PubMed]

12. Stemmler, H.J.; Schmitt, M.; Harbeck, N.; Willems, A.; Bernhard, H.; Lassig, D.; Schoenberg, S.; Heinemann, V. Application of intrathecal trastuzumab (Herceptintrade mark) for treatment of meningeal carcinomatosis in HER2-overexpressing metastatic breast cancer. Oncol. Rep. 2006, 15, 1373-1377. [PubMed]

13. Wolak, D.J.; Thorne, R.G. Diffusion of macromolecules in the brain: Implications for drug delivery. Mol. Pharm. 2013, 10, 1492-1504. [CrossRef] [PubMed]

14. Jessen, N.A.; Munk, A.S.; Lundgaard, I.; Nedergaard, M. The Glymphatic System: A Beginner's Guide. Neurochem. Res. 2015, 40, 2583-2599. [CrossRef]

15. Cserr, H.F.; Ostrach, L.H. Bulk flow of interstitial fluid after intracranial injection of blue dextran 2000. Exp. Neurol. 1974, 45, 50-60. [CrossRef]

16. Neuroscience Nedergaard, M. Garbage truck of the brain. Science 2013, 340, 1529-1530. [CrossRef] 
17. Iliff, J.J.; Wang, M.; Liao, Y.; Plogg, B.A.; Peng, W.; Gundersen, G.A.; Benveniste, H.; Vates, G.E.; Deane, R.; Goldman, S.A.; et al. A paravascular pathway facilitates CSF flow through the brain parenchyma and the clearance of interstitial solutes, including amyloid beta. Sci. Transl. Med. 2012, 4, 147ra111. [CrossRef]

18. Mathiisen, T.M.; Lehre, K.P.; Danbolt, N.C.; Ottersen, O.P. The perivascular astroglial sheath provides a complete covering of the brain microvessels: An electron microscopic 3D reconstruction. Glia 2010, 58, 1094-1103. [CrossRef]

19. Zhou, J.; Kong, H.; Hua, X.; Xiao, M.; Ding, J.; Hu, G. Altered blood-brain barrier integrity in adult aquaporin-4 knockout mice. Neuroreport 2008, 19, 1-5. [CrossRef]

20. Kress, B.T.; Iliff, J.J.; Xia, M.; Wang, M.; Wei, H.S.; Zeppenfeld, D.; Xie, L.; Kang, H.; Xu, Q.; Liew, J.A.; et al. Impairment of paravascular clearance pathways in the aging brain. Ann. Neurol. 2014, 76, 845-861. [CrossRef]

21. Schroth, G.; Klose, U. Cerebrospinal fluid flow. I. Physiology of cardiac-related pulsation. Neuroradiology 1992, 35, 10-15. [CrossRef] [PubMed]

22. Zieman, S.J.; Melenovsky, V.; Kass, D.A. Mechanisms, pathophysiology, and therapy of arterial stiffness. Arterioscler. Thromb. Vasc. Biol. 2005, 25, 932-943. [CrossRef] [PubMed]

23. Chen, R.L.; Kassem, N.A.; Redzic, Z.B.; Chen, C.P.; Segal, M.B.; Preston, J.E. Age-related changes in choroid plexus and blood-cerebrospinal fluid barrier function in the sheep. Exp. Gerontol. 2009, 44, 289-296. [CrossRef]

24. Fleischman, D.; Berdahl, J.P.; Zaydlarova, J.; Stinnett, S.; Fautsch, M.P.; Allingham, R.R. Cerebrospinal fluid pressure decreases with older age. PLOS ONE 2012, 7, e52664. [CrossRef]

25. Xie, L.; Kang, H.; Xu, Q.; Chen, M.J.; Liao, Y.; Thiyagarajan, M.; O’Donnell, J.; Christensen, D.J.; Nicholson, C.; Iliff, J.J.; et al. Sleep drives metabolite clearance from the adult brain. Science 2013, 342, 373-377. [CrossRef]

26. Szentistvanyi, I.; Patlak, C.S.; Ellis, R.A.; Cserr, H.F. Drainage of interstitial fluid from different regions of rat brain. Am. J. Physiol. 1984, 246, F835-F844. [CrossRef]

27. Cserr, H.F.; Cooper, D.N.; Milhorat, T.H. Flow of cerebral interstitial fluid as indicated by the removal of extracellular markers from rat caudate nucleus. Exp. Eye Res. 1977, 25, 461-473. [CrossRef]

28. Bradbury, M.W.; Cserr, H.F.; Westrop, R.J. Drainage of cerebral interstitial fluid into deep cervical lymph of the rabbit. Am. J. Physiol. 1981, 240, F329-F336. [CrossRef]

29. Cserr, H.F.; Cooper, D.N.; Suri, P.K.; Patlak, C.S. Efflux of radiolabeled polyethylene glycols and albumin from rat brain. Am. J. Physiol. 1981, 240, F319-F328. [CrossRef]

30. Zagouri, F.; Sergentanis, T.N.; Bartsch, R.; Berghoff, A.S.; Chrysikos, D.; de Azambuja, E.; Dimopoulos, M.A.; Preusser, M. Intrathecal administration of trastuzumab for the treatment of meningeal carcinomatosis in HER2-positive metastatic breast cancer: A systematic review and pooled analysis. Breast Cancer Res. Treat. 2013, 139, 13-22. [CrossRef]

31. Hopkins, K.; Kemshead, J.T. Progress review: Intrathecal and intratumoral injection of radiolabelled monoclonal antibodies (MoAbs) for the treatment of central nervous system (CNS) malignancies. J. Drug. Target. 1993, 1, 175-183. [CrossRef]

32. Schinkel, A.H.; Wagenaar, E.; Mol, C.A.; van Deemter, L. P-glycoprotein in the blood-brain barrier of mice influences the brain penetration and pharmacological activity of many drugs. J. Clin. Investig. 1996, 97, 2517-2524. [CrossRef]

33. Zhang, Y.; Pardridge, W.M. Mediated efflux of IgG molecules from brain to blood across the blood-brain barrier. J. Neuroimmunol. 2001, 114, 168-172. [CrossRef]

34. Abbott, N.J. Blood-brain barrier structure and function and the challenges for CNS drug delivery. J. Inherit. Metab. Dis. 2013, 36, 437-449. [CrossRef]

35. Loscher, W.; Potschka, H. Drug resistance in brain diseases and the role of drug efflux transporters. Nat. Rev. Neurosci. 2005, 6, 591-602. [CrossRef]

36. Robey, R.W.; Pluchino, K.M.; Hall, M.D.; Fojo, A.T.; Bates, S.E.; Gottesman, M.M. Revisiting the role of ABC transporters in multidrug-resistant cancer. Nat. Rev. Cancer 2018, 18, 452-464. [CrossRef]

37. Loscher, W.; Potschka, H.; Sisodiya, S.M.; Vezzani, A. Drug Resistance in Epilepsy: Clinical Impact, Potential Mechanisms, and New Innovative Treatment Options. Pharmacol. Rev. 2020, 72, 606-638. [CrossRef]

38. Dean, M.; Rzhetsky, A.; Allikmets, R. The human ATP-binding cassette (ABC) transporter superfamily. Genome Res. 2001, 11, 1156-1166. [CrossRef]

39. Chen, Z.; Shi, T.; Zhang, L.; Zhu, P.; Deng, M.; Huang, C.; Hu, T.; Jiang, L.; Li, J. Mammalian drug efflux transporters of the ATP binding cassette (ABC) family in multidrug resistance: A review of the past decade. Cancer Lett. 2016, 370, 153-164. [CrossRef]

40. Ng, W.F.; Sarangi, F.; Zastawny, R.L.; Veinot-Drebot, L.; Ling, V. Identification of members of the P-glycoprotein multigene family. Mol. Cell. Biol. 1989, 9, 1224-1232. [CrossRef]

41. Ueda, K.; Cardarelli, C.; Gottesman, M.M.; Pastan, I. Expression of a full-length cDNA for the human "MDR1" gene confers resistance to colchicine, doxorubicin, and vinblastine. Proc. Natl. Acad. Sci. USA 1987, 84, 3004-3008. [CrossRef] [PubMed]

42. Tang-Wai, D.F.; Kajiji, S.; DiCapua, F.; de Graaf, D.; Roninson, I.B.; Gros, P. Human (MDR1) and mouse (mdr1, mdr3) P-glycoproteins can be distinguished by their respective drug resistance profiles and sensitivity to modulators. Biochemistry 1995, 34, 32-39. [CrossRef] [PubMed]

43. Schinkel, A.H.; Roelofs, E.M.; Borst, P. Characterization of the human MDR3 P-glycoprotein and its recognition by P-glycoproteinspecific monoclonal antibodies. Cancer Res. 1991, 51, 2628-2635.

44. Devault, A.; Gros, P. Two members of the mouse mdr gene family confer multidrug resistance with overlapping but distinct drug specificities. Mol. Cell. Biol. 1990, 10, 1652-1663. [CrossRef] [PubMed] 
45. Juliano, R.L.; Ling, V. A surface glycoprotein modulating drug permeability in Chinese hamster ovary cell mutants. Biochim. Biophys. Acta 1976, 455, 152-162. [CrossRef]

46. Fojo, A.T.; Ueda, K.; Slamon, D.J.; Poplack, D.G.; Gottesman, M.M.; Pastan, I. Expression of a multidrug-resistance gene in human tumors and tissues. Proc. Natl. Acad. Sci. USA 1987, 84, 265-269. [CrossRef]

47. Thiebaut, F.; Tsuruo, T.; Hamada, H.; Gottesman, M.M.; Pastan, I.; Willingham, M.C. Cellular localization of the multidrugresistance gene product P-glycoprotein in normal human tissues. Proc. Natl. Acad. Sci. USA 1987, 84, 7735-7738. [CrossRef]

48. Bello-Reuss, E.; Ernest, S. Expression and function of P-glycoprotein in human mesangial cells. Am. J. Physiol. 1994, 267, C1351-C1358. [CrossRef]

49. Cordon-Cardo, C.; O’Brien, J.P.; Casals, D.; Rittman-Grauer, L.; Biedler, J.L.; Melamed, M.R.; Bertino, J.R. Multidrug-resistance gene (P-glycoprotein) is expressed by endothelial cells at blood-brain barrier sites. Proc. Natl. Acad. Sci. USA 1989, 86, 695-698. [CrossRef]

50. Stewart, P.A.; Beliveau, R.; Rogers, K.A. Cellular localization of P-glycoprotein in brain versus gonadal capillaries. J. Histochem. Cytochem. 1996, 44, 679-685. [CrossRef]

51. Thiebaut, F.; Tsuruo, T.; Hamada, H.; Gottesman, M.M.; Pastan, I.; Willingham, M.C. Immunohistochemical localization in normal tissues of different epitopes in the multidrug transport protein P170: Evidence for localization in brain capillaries and crossreactivity of one antibody with a muscle protein. J. Histochem. Cytochem. 1989, 37, 159-164. [CrossRef] [PubMed]

52. Pardridge, W.M.; Golden, P.L.; Kang, Y.S.; Bickel, U. Brain microvascular and astrocyte localization of P-glycoprotein. J. Neurochem. 1997, 68, 1278-1285. [CrossRef] [PubMed]

53. Jette, L.; Tetu, B.; Beliveau, R. High levels of P-glycoprotein detected in isolated brain capillaries. Biochim. Biophys. Acta 1993, 1150, 147-154. [CrossRef]

54. Schinkel, A.H.; Smit, J.J.; van Tellingen, O.; Beijnen, J.H.; Wagenaar, E.; van Deemter, L.; Mol, C.A.; van der Valk, M.A.; RobanusMaandag, E.C.; te Riele, H.P.; et al. Disruption of the mouse mdrla P-glycoprotein gene leads to a deficiency in the blood-brain barrier and to increased sensitivity to drugs. Cell 1994, 77, 491-502. [CrossRef]

55. Riordan, J.R.; Deuchars, K.; Kartner, N.; Alon, N.; Trent, J.; Ling, V. Amplification of P-glycoprotein genes in multidrug-resistant mammalian cell lines. Nature 1985, 316, 817-819. [CrossRef]

56. Xu, D.; Knaust, E.; Pisa, P.; Palucka, K.; Lundeberg, J.; Arestrom, I.; Peterson, C.; Gruber, A. Levels of mdr1 and mrp mRNA in leukaemic cell populations from patients with acute myelocytic leukaemia are heterogenous and inversely correlated to cellular daunorubicin accumulation. Br. J. Haematol. 1996, 92, 847-854. [CrossRef]

57. Chan, G.N.; Patel, R.; Cummins, C.L.; Bendayan, R. Induction of P-glycoprotein by antiretroviral drugs in human brain microvessel endothelial cells. Antimicrob. Agents Chemother. 2013, 57, 4481-4488. [CrossRef]

58. Chan, G.N.; Saldivia, V.; Yang, Y.; Pang, H.; de Lannoy, I.; Bendayan, R. In vivo induction of P-glycoprotein expression at the mouse blood-brain barrier: An intracerebral microdialysis study. J. Neurochem. 2013, 127, 342-352. [CrossRef]

59. Fallacara, A.L.; Zamperini, C.; Podolski-Renic, A.; Dinic, J.; Stankovic, T.; Stepanovic, M.; Mancini, A.; Rango, E.; Iovenitti, G.; Molinari, A.; et al. A New Strategy for Glioblastoma Treatment: In Vitro and In Vivo Preclinical Characterization of Si306, a Pyrazolo[3,4-d]Pyrimidine Dual Src/P-Glycoprotein Inhibitor. Cancers 2019, 11, 848. [CrossRef]

60. Elkhayat, H.A.; Aly, R.H.; Elagouza, I.A.; El-Kabarity, R.H.; Galal, Y.I. Role of P-glycoprotein inhibitors in children with drug-resistant epilepsy. Acta Neurol. Scand. 2017, 136, 639-644. [CrossRef]

61. Choo, E.F.; Kurnik, D.; Muszkat, M.; Ohkubo, T.; Shay, S.D.; Higginbotham, J.N.; Glaeser, H.; Kim, R.B.; Wood, A.J.; Wilkinson, G.R. Differential in vivo sensitivity to inhibition of P-glycoprotein located in lymphocytes, testes, and the blood-brain barrier. J. Pharmacol. Exp. Ther. 2006, 317, 1012-1018. [CrossRef] [PubMed]

62. Wagner, C.C.; Bauer, M.; Karch, R.; Feurstein, T.; Kopp, S.; Chiba, P.; Kletter, K.; Loscher, W.; Muller, M.; Zeitlinger, M.; et al. A pilot study to assess the efficacy of tariquidar to inhibit P-glycoprotein at the human blood-brain barrier with (R)-11C-verapamil and PET. J. Nucl. Med. 2009, 50, 1954-1961. [CrossRef] [PubMed]

63. Martins, E.; Silva, V.; Lemos, A.; Palmeira, A.; Puthongking, P.; Sousa, E.; Rocha-Pereira, C.; Ghanem, C.I.; Carmo, H.; Remiao, F.; et al. Newly Synthesized Oxygenated Xanthones as Potential P-Glycoprotein Activators: In Vitro, Ex Vivo, and In Silico Studies. Molecules 2019, 24, 707. [CrossRef]

64. Sterz, K.; Mollmann, L.; Jacobs, A.; Baumert, D.; Wiese, M. Activators of P-glycoprotein: Structure-activity relationships and investigation of their mode of action. ChemMedChem 2009, 4, 1897-1911. [CrossRef]

65. Cooray, H.C.; Blackmore, C.G.; Maskell, L.; Barrand, M.A. Localisation of breast cancer resistance protein in microvessel endothelium of human brain. Neuroreport 2002, 13, 2059-2063. [CrossRef] [PubMed]

66. Eisenblatter, T.; Huwel, S.; Galla, H.J. Characterisation of the brain multidrug resistance protein (BMDP/ABCG2/BCRP) expressed at the blood-brain barrier. Brain Res. 2003, 971, 221-231. [CrossRef]

67. Litman, T.; Brangi, M.; Hudson, E.; Fetsch, P.; Abati, A.; Ross, D.D.; Miyake, K.; Resau, J.H.; Bates, S.E. The multidrug-resistant phenotype associated with overexpression of the new ABC half-transporter, MXR (ABCG2). J. Cell Sci. 2000, 113 Pt 11, $2011-2021$.

68. Burger, H.; van Tol, H.; Boersma, A.W.; Brok, M.; Wiemer, E.A.; Stoter, G.; Nooter, K. Imatinib mesylate (STI571) is a substrate for the breast cancer resistance protein (BCRP)/ABCG2 drug pump. Blood 2004, 104, 2940-2942. [CrossRef]

69. Yanase, K.; Tsukahara, S.; Asada, S.; Ishikawa, E.; Imai, Y.; Sugimoto, Y. Gefitinib reverses breast cancer resistance proteinmediated drug resistance. Mol. Cancer Ther. 2004, 3, 1119-1125.

70. Agarwal, S.; Sane, R.; Ohlfest, J.R.; Elmquist, W.F. The role of the breast cancer resistance protein (ABCG2) in the distribution of sorafenib to the brain. J. Pharmacol. Exp. Ther. 2011, 336, 223-233. [CrossRef] 
71. Cisternino, S.; Mercier, C.; Bourasset, F.; Roux, F.; Scherrmann, J.M. Expression, up-regulation, and transport activity of the multidrug-resistance protein Abcg2 at the mouse blood-brain barrier. Cancer Res. 2004, 64, 3296-3301. [CrossRef] [PubMed]

72. Durmus, S.; Xu, N.; Sparidans, R.W.; Wagenaar, E.; Beijnen, J.H.; Schinkel, A.H. P-glycoprotein (MDR1/ABCB1) and breast cancer resistance protein (BCRP/ABCG2) restrict brain accumulation of the JAK1/2 inhibitor, CYT387. Pharmacol. Res. 2013, 76, 9-16. [CrossRef] [PubMed]

73. Li, L.; Agarwal, S.; Elmquist, W.F. Brain efflux index to investigate the influence of active efflux on brain distribution of pemetrexed and methotrexate. Drug. Metab. Dispos. 2013, 41, 659-667. [CrossRef]

74. Sane, R.; Agarwal, S.; Mittapalli, R.K.; Elmquist, W.F. Saturable active efflux by p-glycoprotein and breast cancer resistance protein at the blood-brain barrier leads to nonlinear distribution of elacridar to the central nervous system. J. Pharmacol. Exp. Ther. 2013, 345, 111-124. [CrossRef] [PubMed]

75. Kodaira, H.; Kusuhara, H.; Ushiki, J.; Fuse, E.; Sugiyama, Y. Kinetic analysis of the cooperation of P-glycoprotein (P-gp/Abcb1) and breast cancer resistance protein (Bcrp/Abcg2) in limiting the brain and testis penetration of erlotinib, flavopiridol, and mitoxantrone. J. Pharmacol. Exp. Ther. 2010, 333, 788-796. [CrossRef] [PubMed]

76. Poller, B.; Wagenaar, E.; Tang, S.C.; Schinkel, A.H. Double-transduced MDCKII cells to study human P-glycoprotein (ABCB1) and breast cancer resistance protein (ABCG2) interplay in drug transport across the blood-brain barrier. Mol. Pharm. 2011, 8, 571-582. [CrossRef] [PubMed]

77. Nies, A.T.; Jedlitschky, G.; Konig, J.; Herold-Mende, C.; Steiner, H.H.; Schmitt, H.P.; Keppler, D. Expression and immunolocalization of the multidrug resistance proteins, MRP1-MRP6 (ABCC1-ABCC6), in human brain. Neuroscience 2004, 129, 349-360. [CrossRef]

78. Soontornmalai, A.; Vlaming, M.L.; Fritschy, J.M. Differential, strain-specific cellular and subcellular distribution of multidrug transporters in murine choroid plexus and blood-brain barrier. Neuroscience 2006, 138, 159-169. [CrossRef]

79. Zhang, Y.; Han, H.; Elmquist, W.F.; Miller, D.W. Expression of various multidrug resistance-associated protein (MRP) homologues in brain microvessel endothelial cells. Brain. Res. 2000, 876, 148-153. [CrossRef]

80. Barrand, M.A.; Bagrij, T.; Neo, S.Y. Multidrug resistance-associated protein: A protein distinct from P-glycoprotein involved in cytotoxic drug expulsion. Gen. Pharmacol. 1997, 28, 639-645. [CrossRef]

81. Seelig, A.; Blatter, X.L.; Wohnsland, F. Substrate recognition by P-glycoprotein and the multidrug resistance-associated protein MRP1: A comparison. Int. J. Clin. Pharmacol. Ther. 2000, 38, 111-121. [CrossRef] [PubMed]

82. Sparreboom, A.; van Asperen, J.; Mayer, U.; Schinkel, A.H.; Smit, J.W.; Meijer, D.K.; Borst, P.; Nooijen, W.J.; Beijnen, J.H.; van Tellingen, $\mathrm{O}$. Limited oral bioavailability and active epithelial excretion of paclitaxel (Taxol) caused by P-glycoprotein in the intestine. Proc. Natl. Acad. Sci. USA 1997, 94, 2031-2035. [CrossRef] [PubMed]

83. Allen, J.D.; Brinkhuis, R.F.; van Deemter, L.; Wijnholds, J.; Schinkel, A.H. Extensive contribution of the multidrug transporters P-glycoprotein and Mrp1 to basal drug resistance. Cancer Res. 2000, 60, 5761-5766. [PubMed]

84. van Waterschoot, R.A.; Lagas, J.S.; Wagenaar, E.; Rosing, H.; Beijnen, J.H.; Schinkel, A.H. Individual and combined roles of CYP3A, P-glycoprotein (MDR1/ABCB1) and MRP2 (ABCC2) in the pharmacokinetics of docetaxel. Int. J. Cancer 2010, 127, 2959-2964. [CrossRef] [PubMed]

85. Ballard, P.; Yates, J.W.; Yang, Z.; Kim, D.W.; Yang, J.C.; Cantarini, M.; Pickup, K.; Jordan, A.; Hickey, M.; Grist, M.; et al. Preclinical Comparison of Osimertinib with Other EGFR-TKIs in EGFR-Mutant NSCLC Brain Metastases Models, and Early Evidence of Clinical Brain Metastases Activity. Clin. Cancer Res. 2016, 22, 5130-5140. [CrossRef]

86. Soria, J.C.; Ohe, Y.; Vansteenkiste, J.; Reungwetwattana, T.; Chewaskulyong, B.; Lee, K.H.; Dechaphunkul, A.; Imamura, F.; Nogami, N.; Kurata, T.; et al. Osimertinib in Untreated EGFR-Mutated Advanced Non-Small-Cell Lung Cancer. N. Engl. J. Med. 2018, 378, 113-125. [CrossRef] [PubMed]

87. Stephens, R.H.; O’Neill, C.A.; Warhurst, A.; Carlson, G.L.; Rowland, M.; Warhurst, G. Kinetic profiling of P-glycoprotein-mediated drug efflux in rat and human intestinal epithelia. J. Pharmacol. Exp. Ther. 2001, 296, 584-591.

88. Richter, M.; Gyemant, N.; Molnar, J.; Hilgeroth, A. Comparative effects on intestinal absorption in situ by P-glycoproteinmodifying HIV protease inhibitors. Pharm. Res. 2004, 21, 1862-1866. [CrossRef]

89. Hendrikse, N.H.; Franssen, E.J.; van der Graaf, W.T.; Vaalburg, W.; de Vries, E.G. Visualization of multidrug resistance in vivo. Eur. J. Nucl. Med. 1999, 26, 283-293. [CrossRef]

90. Evers, R.; de Haas, M.; Sparidans, R.; Beijnen, J.; Wielinga, P.R.; Lankelma, J.; Borst, P. Vinblastine and sulfinpyrazone export by the multidrug resistance protein MRP2 is associated with glutathione export. Br. J. Cancer 2000, 83, 375-383. [CrossRef]

91. Chu, X.Y.; Suzuki, H.; Ueda, K.; Kato, Y.; Akiyama, S.; Sugiyama, Y. Active efflux of CPT-11 and its metabolites in human KB-derived cell lines. J. Pharmacol. Exp. Ther. 1999, 288, 735-741. [PubMed]

92. Hirohashi, T.; Suzuki, H.; Sugiyama, Y. Characterization of the transport properties of cloned rat multidrug resistance-associated protein 3 (MRP3). J. Biol. Chem. 1999, 274, 15181-15185. [CrossRef] [PubMed]

93. Kemper, E.M.; van Zandbergen, A.E.; Cleypool, C.; Mos, H.A.; Boogerd, W.; Beijnen, J.H.; van Tellingen, O. Increased penetration of paclitaxel into the brain by inhibition of P-Glycoprotein. Clin. Cancer Res. 2003, 9, 2849-2855. [PubMed]

94. Kemper, E.M.; Verheij, M.; Boogerd, W.; Beijnen, J.H.; van Tellingen, O. Improved penetration of docetaxel into the brain by co-administration of inhibitors of P-glycoprotein. Eur. J. Cancer 2004, 40, 1269-1274. [CrossRef] [PubMed]

95. O'Brien, F.E.; O'Connor, R.M.; Clarke, G.; Dinan, T.G.; Griffin, B.T.; Cryan, J.F. P-glycoprotein inhibition increases the brain distribution and antidepressant-like activity of escitalopram in rodents. Neuropsychopharmacology 2013, 38, 2209-2219. [CrossRef] [PubMed] 
96. Ejsing, T.B.; Linnet, K. Influence of P-glycoprotein inhibition on the distribution of the tricyclic antidepressant nortriptyline over the blood-brain barrier. Hum. Psychopharmacol. 2005, 20, 149-153. [CrossRef] [PubMed]

97. O’Brien, F.E.; Clarke, G.; Fitzgerald, P.; Dinan, T.G.; Griffin, B.T.; Cryan, J.F. Inhibition of P-glycoprotein enhances transport of imipramine across the blood-brain barrier: Microdialysis studies in conscious freely moving rats. Br. J. Pharmacol. 2012, 166, 1333-1343. [CrossRef]

98. Sadiq, M.W.; Uchida, Y.; Hoshi, Y.; Tachikawa, M.; Terasaki, T.; Hammarlund-Udenaes, M. Validation of a P-Glycoprotein (P-gp) Humanized Mouse Model by Integrating Selective Absolute Quantification of Human MDR1, Mouse Mdr1a and Mdr1b Protein Expressions with In Vivo Functional Analysis for Blood-Brain Barrier Transport. PLoS ONE 2015, 10, e0118638. [CrossRef]

99. Kemper, E.M.; Cleypool, C.; Boogerd, W.; Beijnen, J.H.; van Tellingen, O. The influence of the P-glycoprotein inhibitor zosuquidar trihydrochloride (LY335979) on the brain penetration of paclitaxel in mice. Cancer Chemother. Pharmacol. 2004, 53, 173-178. [CrossRef]

100. Dai, H.; Marbach, P.; Lemaire, M.; Hayes, M.; Elmquist, W.F. Distribution of STI-571 to the brain is limited by P-glycoproteinmediated efflux. J. Pharmacol. Exp. Ther. 2003, 304, 1085-1092. [CrossRef]

101. Tang, S.C.; Lagas, J.S.; Lankheet, N.A.; Poller, B.; Hillebrand, M.J.; Rosing, H.; Beijnen, J.H.; Schinkel, A.H. Brain accumulation of sunitinib is restricted by P-glycoprotein (ABCB1) and breast cancer resistance protein (ABCG2) and can be enhanced by oral elacridar and sunitinib coadministration. Int. J. Cancer 2012, 130, 223-233. [CrossRef] [PubMed]

102. Tang, S.C.; Lankheet, N.A.; Poller, B.; Wagenaar, E.; Beijnen, J.H.; Schinkel, A.H. P-glycoprotein (ABCB1) and breast cancer resistance protein (ABCG2) restrict brain accumulation of the active sunitinib metabolite N-desethyl sunitinib. J. Pharmacol. Exp. Ther. 2012, 341, 164-173. [CrossRef] [PubMed]

103. Karbownik, A.; Sobanska, K.; Plotek, W.; Grabowski, T.; Klupczynska, A.; Plewa, S.; Grzeskowiak, E.; Szalek, E. The influence of the coadministration of the p-glycoprotein modulator elacridar on the pharmacokinetics of lapatinib and its distribution in the brain and cerebrospinal fluid. Investig. New Drugs 2020, 38, 574-583. [CrossRef] [PubMed]

104. Durmus, S.; Sparidans, R.W.; Wagenaar, E.; Beijnen, J.H.; Schinkel, A.H. Oral availability and brain penetration of the B-RAFV600E inhibitor vemurafenib can be enhanced by the P-GLYCOprotein (ABCB1) and breast cancer resistance protein (ABCG2) inhibitor elacridar. Mol. Pharm. 2012, 9, 3236-3245. [CrossRef]

105. Tang, S.C.; Nguyen, L.N.; Sparidans, R.W.; Wagenaar, E.; Beijnen, J.H.; Schinkel, A.H. Increased oral availability and brain accumulation of the ALK inhibitor crizotinib by coadministration of the P-glycoprotein (ABCB1) and breast cancer resistance protein (ABCG2) inhibitor elacridar. Int. J. Cancer 2014, 134, 1484-1494. [CrossRef]

106. Agarwal, S.; Sane, R.; Gallardo, J.L.; Ohlfest, J.R.; Elmquist, W.F. Distribution of gefitinib to the brain is limited by P-glycoprotein (ABCB1) and breast cancer resistance protein (ABCG2)-mediated active efflux. J. Pharmacol. Exp. Ther. 2010, 334, 147-155. [CrossRef]

107. Drion, N.; Lemaire, M.; Lefauconnier, J.M.; Scherrmann, J.M. Role of P-glycoprotein in the blood-brain transport of colchicine and vinblastine. J. Neurochem. 1996, 67, 1688-1693. [CrossRef]

108. Israel, E.J.; Taylor, S.; Wu, Z.; Mizoguchi, E.; Blumberg, R.S.; Bhan, A.; Simister, N.E. Expression of the neonatal Fc receptor, FcRn, on human intestinal epithelial cells. Immunology 1997, 92, 69-74. [CrossRef]

109. Antohe, F.; Radulescu, L.; Gafencu, A.; Ghetie, V.; Simionescu, M. Expression of functionally active FcRn and the differentiated bidirectional transport of IgG in human placental endothelial cells. Hum. Immunol. 2001, 62, 93-105. [CrossRef]

110. Leach, J.L.; Sedmak, D.D.; Osborne, J.M.; Rahill, B.; Lairmore, M.D.; Anderson, C.L. Isolation from human placenta of the IgG transporter, FcRn, and localization to the syncytiotrophoblast: Implications for maternal-fetal antibody transport. J. Immunol. 1996, 157, 3317-3322.

111. Roopenian, D.C.; Akilesh, S. FcRn: The neonatal Fc receptor comes of age. Nat. Rev. Immunol. 2007, 7, 715-725. [CrossRef] [PubMed]

112. Schlachetzki, F.; Zhu, C.; Pardridge, W.M. Expression of the neonatal Fc receptor (FcRn) at the blood-brain barrier. J. Neurochem. 2002, 81, 203-206. [CrossRef] [PubMed]

113. Cooper, P.R.; Ciambrone, G.J.; Kliwinski, C.M.; Maze, E.; Johnson, L.; Li, Q.; Feng, Y.; Hornby, P.J. Efflux of monoclonal antibodies from rat brain by neonatal Fc receptor, FcRn. Brain Res. 2013, 1534, 13-21. [CrossRef] [PubMed]

114. Ober, R.J.; Martinez, C.; Vaccaro, C.; Zhou, J.; Ward, E.S. Visualizing the site and dynamics of IgG salvage by the MHC class I-related receptor, FcRn. J. Immunol. 2004, 172, 2021-2029. [CrossRef] [PubMed]

115. Chen, Y.; Liu, L. Modern methods for delivery of drugs across the blood-brain barrier. Adv. Drug. Deliv. Rev. 2012, 64, 640-665. [CrossRef]

116. Rubenstein, J.L.; Fridlyand, J.; Abrey, L.; Shen, A.; Karch, J.; Wang, E.; Issa, S.; Damon, L.; Prados, M.; McDermott, M.; et al. Phase I study of intraventricular administration of rituximab in patients with recurrent CNS and intraocular lymphoma. J. Clin. Oncol. 2007, 25, 1350-1356. [CrossRef]

117. Zylber-Katz, E.; Gomori, J.M.; Schwartz, A.; Lossos, A.; Bokstein, F.; Siegal, T. Pharmacokinetics of methotrexate in cerebrospinal fluid and serum after osmotic blood-brain barrier disruption in patients with brain lymphoma. Clin. Pharmacol. Ther. 2000, 67, 631-641. [CrossRef]

118. Morikawa, N.; Mori, T.; Abe, T.; Kawashima, H.; Takeyama, M.; Hori, S. Pharmacokinetics of etoposide and carboplatin in cerebrospinal fluid and plasma during hyperosmotic disruption of the blood brain barrier and intraarterial combination chemotherapy. Biol. Pharm. Bull. 1999, 22, 428-431. [CrossRef]

119. Brightman, M.W.; Hori, M.; Rapoport, S.I.; Reese, T.S.; Westergaard, E. Osmotic opening of tight junctions in cerebral endothelium. J. Comp. Neurol. 1973, 152, 317-325. [CrossRef] 
120. Knuutinen, O.; Kuitunen, H.; Alahuhta, S.; Isokangas, J.M.; Sonkajarvi, E.; Turpeenniemi-Hujanen, T.; Kuittinen, O. Case Report: Chemotherapy in Conjunction With Blood-Brain Barrier Disruption for a Patient With Germ Cell Tumor With Multiple Brain Metastases. Clin. Genitourin. Cancer 2018, 16, e993-e996. [CrossRef]

121. Fortin, D.; Gendron, C.; Boudrias, M.; Garant, M.P. Enhanced chemotherapy delivery by intraarterial infusion and blood-brain barrier disruption in the treatment of cerebral metastasis. Cancer 2007, 109, 751-760. [CrossRef] [PubMed]

122. Haluska, M.; Anthony, M.L. Osmotic blood-brain barrier modification for the treatment of malignant brain tumors. Clin. J. Oncol. Nurs. 2004, 8, 263-267. [CrossRef] [PubMed]

123. Chen, C.H.; Toung, T.J.; Sapirstein, A.; Bhardwaj, A. Effect of duration of osmotherapy on blood-brain barrier disruption and regional cerebral edema after experimental stroke. J. Cereb. Blood Flow Metab. 2006, 26, 951-958. [CrossRef] [PubMed]

124. Zeng, Y.D.; Liao, H.; Qin, T.; Zhang, L.; Wei, W.D.; Liang, J.Z.; Xu, F.; Dinglin, X.X.; Ma, S.X.; Chen, L.K. Blood-brain barrier permeability of gefitinib in patients with brain metastases from non-small-cell lung cancer before and during whole brain radiation therapy. Oncotarget 2015, 6, 8366-8376. [CrossRef]

125. Pollack, I.F.; Stewart, C.F.; Kocak, M.; Poussaint, T.Y.; Broniscer, A.; Banerjee, A.; Douglas, J.G.; Kun, L.E.; Boyett, J.M.; Geyer, J.R. A phase II study of gefitinib and irradiation in children with newly diagnosed brainstem gliomas: A report from the Pediatric Brain Tumor Consortium. Neuro. Oncol. 2011, 13, 290-297. [CrossRef]

126. Yang, F.Y.; Lin, G.L.; Horng, S.C.; Chang, T.K.; Wu, S.Y.; Wong, T.T.; Wang, H.E. Pulsed high-intensity focused ultrasound enhances the relative permeability of the blood-tumor barrier in a glioma-bearing rat model. IEEE Trans. Ultrason. Ferroelectr. Freq. Control 2011, 58, 964-970. [CrossRef]

127. Liu, X.F.; Fawcett, J.R.; Thorne, R.G.; DeFor, T.A.; Frey, W.H. 2nd, Intranasal administration of insulin-like growth factor-I bypasses the blood-brain barrier and protects against focal cerebral ischemic damage. J. Neurol. Sci. 2001, 187, 91-97. [CrossRef]

128. Nguyen, T.T.; Angeli, E.; Darrouzain, F.; Nguyen, Q.T.; Desvignes, C.; Rigal, M.; Nevine, O.; Nicolas, P.; Le, Q.V.; Winterman, S.; et al. A successful compartmental approach for the treatment of breast cancer brain metastases. Cancer Chemother. Pharmacol. 2019, 83, 573-580. [CrossRef]

129. Bousquet, G.; Darrouzain, F.; de Bazelaire, C.; Ternant, D.; Barranger, E.; Winterman, S.; Madelaine-Chambin, I.; Thiebaut, J.B.; Polivka, M.; Paintaud, G.; et al. Intrathecal Trastuzumab Halts Progression of CNS Metastases in Breast Cancer. J. Clin. Oncol. 2016, 34, e151-e155. [CrossRef]

130. Hosoda, T.; Katayama, M. Epidemiology and prognosis of ommaya reservoir-related bacterial meningitis in adult patients with leptomeningeal metastases from solid tumors: A 10-year retrospective single-center study in Japan. J. Infect. Chemother. 2020. [CrossRef]

131. Bousquet, G.; Janin, A. Patient-Derived Xenograft: An Adjuvant Technology for the Treatment of Metastatic Disease. Pathobiology 2016, 83, 170-176. [CrossRef] [PubMed] 